\title{
Spatial and temporal dynamics and parameters of growth of toxic cyanobacteria in Nuwara wewa and Nachchaduwa wewa in Sri Lanka
}

\author{
Mohamed Cassim Mohamed Zakeel ${ }^{1}$, Prathiba Aruni Weerasinghe ${ }^{1, *}$, \\ Banumu Arachchige Dilhani Ganga Kumari ${ }^{2}$, Hetti Arachchige Mangalika Wickremasinghe ${ }^{3}$ \\ ${ }^{1}$ Department of Plant Sciences, Faculty of Agriculture, Rajarata University of Sri Lanka, Puliyankulama, Anuradhapura, Sri Lanka \\ ${ }^{2}$ Postgraduate Institute of Agriculture, University of Peradeniya, Peradeniya, Sri Lanka \\ ${ }^{3}$ Department of Agricultural Biology, Faculty of Agriculture, University of Peradeniya, Peradeniya, Sri Lanka
}

\section{Email address:}

zakeelag48@yahoo.com (M. C. M. Zakeel), aruni500@yahoo.com (P. A. Weerasinghe), dilkumari@yahoo.com (B. A. D. G. Kumari), mangalikaw@pdn.ac.lk (H. A. M. Wickremasinghe)

\section{To cite this article:}

Mohamed Cassim Mohamed Zakeel, Prathiba Aruni Weerasinghe, Banumu Arachchige Dilhani Ganga Kumari, Hetti Arachchige Mangalika Wickremasinghe. Spatial and Temporal Dynamics and Parameters of Growth of Toxic Cyanobacteria in Nuwara Wewa and Nachchaduwa Wewa in Sri Lanka. American Journal of Environmental Protection. Vol. 4, No. 1, 2015, pp. 23-28. doi: 10.11648/j.ajep.20150401.13

\begin{abstract}
Cyanobacterial toxins available in drinking water pose a major health problem to humans and animals. Nuwara wewa and Nachchaduwa wewa are two important reservoirs supplying water for domestic purposes in Anuradhapura, Sri Lanka. As cyanobacterial toxins are resistant to deactivation by heat, it is important to control the proliferation of cyanobacteria in these reservoirs. Therefore, making an inventory of cyanobacterial variations with respect to time and space is imperative. Distinct temporal variations of temperature, $\mathrm{pH}$, turbidity, dissolved oxygen and cyanobacteria density were observed in both reservoirs. Strong positive correlations existed between the above physico-chemical parameters of water and the cyanobacterial density in both reservoirs. These parameters can therefore be used as good indicators to assess the status these reservoirs with respect to cyanobacterial density and distribution.
\end{abstract}

Keywords: Cyanobacterial Toxins, Chronic Renal Failure, Microcystin, Cyanobacterial Bloom, Nuwara Wewa, Nachchaduwa Wewa

\section{Introduction}

Chronic renal failure of unknown etiology is a major health issue in Anuradhapura district which is one of the hotspots of chronic renal failure of unknown etiology in Sri Lanka. Although many factors such as excessive cadmium in drinking water and food stuff especially rice, high level of fluoride in drinking water, use of low quality aluminium utensils for cooking, presence of arsenic in hard water with higher levels of minerals and toxins generated by cyanobacteria are suspected to be contributing to this disease [1], a recent study in Sri Lanka has proved that one of the major causal agents for renal failure is cyanobacterial toxins which cannot be easily removed by boiling [2]. As stated in [3], toxic cyanobacterial blooms in fresh waters pose a health risk to people due to the production of toxic compounds such as microcystins and nodularin. Acute exposure to microcystins, which is the most widespread cyanobacterial toxin present in fresh waters, can cause liver failure and death [4] whereas exposure to low levels of microcystins causes chronic effects in humans $[5,6$, $7,8,9]$.

Ionization and cupric treatments are the only promising measures to get rid of the cyanobacterial toxins [10]. Cupric treatment kills the toxic cyanobacteria and it seems to be highly potential. More than $0.05 \mathrm{mg} / 1$ of Copper can be toxic to algae. Copper is an essential nutrient for animals at low concentration while toxic at higher concentration [11]. However, frequent use of this treatment is not advisable as other types of organisms may also be executed. Nuwara wewa and Nachchaduwa wewa are two important reservoirs serving as major sources of water for domestic purposes. People take water either directly from these reservoirs or irrigations 
channels from these reservoirs or even as tap-borne water supplied by the National Water Supply and Drainage Board in Sri Lanka.

Therefore, it is important to make an inventory of toxic cyanobacteria that populate Nuwara wewa and Nachchaduwa wewa and their seasonal dynamics with the variation of physical and chemical parameters of the water in the lakes. This will help in applying measures to prevent the growth of toxic cyanobacteria and the accumulation of cyanobacterial toxins in drinking water. This study therefore investigated the space-time dynamics of toxic cyanobacteria that populated the Nuwara wewa and Nachchaduwa wewa in Anuradhapura

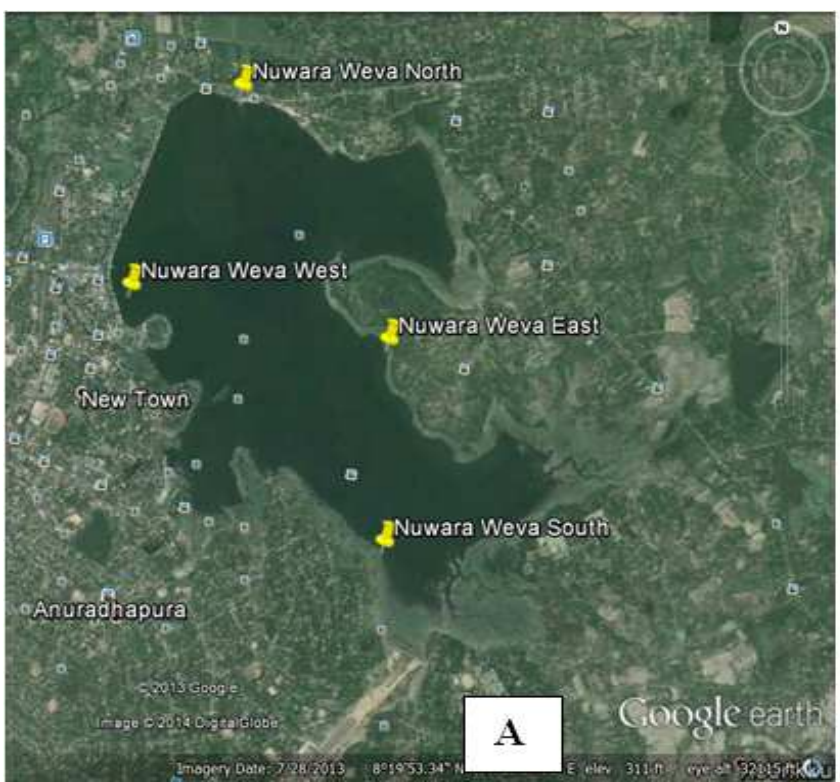

district during January - December, 2012.

\section{Materials and Methods}

\subsection{Study Site}

Two man-made reservoirs namely Nuwara wewa $\left(8^{0}\right.$ 20'08.95" North (N) and $80^{\circ} 25^{\prime} 34.19$ " East (E) with an elevation of 292 feet) and Nachchaduwa wewa $\left(8^{0} 14^{\prime} 51.07^{\prime \prime}\right.$ $\mathrm{N}$ and $80^{\circ} 29^{\prime} 05.25^{\prime \prime} \mathrm{E}$ with an elevation of 342 feet) in Anuradhapura were selected for sampling in this study (Figure $1)$.



Figure 1. Sampling sites in Nuwara wewa (A) and Nachchaduwa wewa (B)

\subsection{Sample Collection}

Water sampling was carried out at four sites by main four directions; North, South, East and West. The coordinates of North, South, East and West sampling sites in Nuwara wewa were $8^{0} 21$ ' $12.94 " \mathrm{~N} \& 80^{\circ} 25$ ' 36.44 " E \& 306 feet, $8^{0}$ $19^{\prime} 06.77^{\prime \prime} \mathrm{N} \& 80^{\circ} 26^{\prime} 10.21^{\prime \prime} \mathrm{E} \& 289$ feet, $8^{0} 20^{\prime} 06.16^{\prime \prime} \mathrm{N} \&$ $80^{\circ} 26^{\prime} 11.55^{\prime}$ " E \& 297 feet and $8^{\circ} 20^{\prime} 25.11$ ' $\mathrm{N} \& 80^{\circ} 25^{\prime}$ 00.23 " E \& 291 feet, respectively (Figure 1). North, South, East and West sampling sites of Nachchaduwa wewa had the coordinates of $8^{0} 16^{\prime} 29.87^{\prime \prime} \mathrm{N} \& 80^{\circ} 28^{\prime} 55.37^{\prime \prime}$ E \& 346 feet, $8^{0} 14^{\prime} 03.17$ "N \& $80^{0} 28$ ' 56.26" E \& 361 feet, $8^{0} 15$ ' 13.73 " N $\& 80^{\circ} 29^{\prime} 13.06^{\prime \prime}$ E \& 345 feet and $8^{0} 15^{\prime} 07.60$ " N \& $80^{\circ} 28^{\prime}$, 13.50 " E \& 335 feet, respectively (Figure 1). The samples were collected from two different layers; surface layer and bottom layer (one meter below the surface), at a rate of three samples per each layer at a sampling site with a total of 24 samples per reservoir per month.

Water samples were collected in sterile brown glass containers every month starting from January 2012 to December 2012. The samples were immediately tested for physico-chemical parameters within a few hours in addition to primary microscopic observations. Formalin solutions of $4 \%$ and $6 \%$ were added into aliquots of samples to prevent the proliferation of cyanobacteria with time in order to preserve the water samples for short and long terms, respectively [12]. For the proliferation of microorganisms, aliquots of samples without formalin were kept under room temperature.

\subsection{Physico-chemical Parameters of Water}

Temperature, $\mathrm{pH}$, dissolved oxygen in water and turbidity were measured as physico-chemical parameters of the collected water samples. The temperature was measured using a standard Celsius thermometer. Turbidity meter (WalkLab) and $\mathrm{pH}$ meter (PCE 228) were used to measure the turbidity and the $\mathrm{pH}$ of water samples, respectively. All these parameters were measured at the time of sampling. The turbidity of water was measured in the unit of Nephelometric Turbidity Units (NTU).

\subsection{Determination of Cyanobacterial Density}

Enumeration of the toxic cyanobacteria was performed under light microscope. A homogenized sample of $0.1 \mathrm{ml}$ was spread out between a slide and a cover slip. The smear was observed according to horizontal course over the entire length of the cover slip [12]. As stated in [12], this operation was repeated five times while shifting clearly over the width of the 
plate, of approximately a field of microscope to avoid overlapping observations. At the time of these five horizontal courses, all cyanobacteria present were enumerated with the magnification of $10 \times 40$ [12]. The average monthly density was calculated using the following formula.

Average Monthly Density $(\mathrm{AMD})=\mathrm{X} .10^{4} / 5 * 4 * 6$

$\mathrm{X}=$ Total number of individuals

$5=$ the number of times the slide prepared with one sample

$4 * 6=$ six samples taken from each of 4 sites

\subsection{Generic Identification of Cyanobacteria}

Collected water samples were concentrated by centrifugation at $3500 \mathrm{rpm}$ for ten minutes. The resultant pellet was serially diluted and inoculated onto BG11 medium to isolate cyanobacteria [13]. The generic identification of cyanobacteria was carried out based on morphological criteria according to keys of identification [14]. Colour, size, shape of colonies and trichome, and the presence of akinete, gas vacuoles, heterocyst and gelatinous sheaths were taken into account [12].

\subsection{Maintenance of Cyanobacterial Cultures}

BG11 medium (Table 1) was prepared to maintain the cyanobacterial cultures [15]. After inoculation, the cultures were incubated at room temperature with 12 hours light-dark cycling until the culture grew well. Sub sampling was done to obtain a pure sample of cyanobacteria for further investigations.

Table 1. Composition of BG 11 Medium

\begin{tabular}{ll}
\hline Ingredients & Quantity/liter \\
\hline $\mathrm{NaNO}_{3}$ & $1.500 \mathrm{~g}$ \\
$\mathrm{~K}_{2} \mathrm{HPO}_{4} .3 \mathrm{H}_{2} \mathrm{O}$ & $0.040 \mathrm{~g}$ \\
$\mathrm{MgSO}_{4} .7 \mathrm{H}_{2} \mathrm{O}$ & $0.075 \mathrm{~g}$ \\
$\mathrm{CaCl}_{2} .2 \mathrm{H}_{2} \mathrm{O}$ & $0.036 \mathrm{~g}$ \\
Citric acid & $0.006 \mathrm{~g}$ \\
Ferric ammonium citrate & $0.006 \mathrm{~g}$ \\
EDTA & $0.001 \mathrm{~g}$ \\
$\mathrm{Na}_{2} \mathrm{CO}_{3}$ & $0.020 \mathrm{~g}$ \\
Trace metal mix A5+Co* & $1.000 \mathrm{~mL}$ \\
Deionized water & $1.000 \mathrm{~L}$ \\
\hline
\end{tabular}

*Trace metal mix should be consisted of $\mathrm{H}_{3} \mathrm{BO}_{3}, 2.86 \mathrm{gl}^{-1} ; \mathrm{MnCl}_{2} .4 \mathrm{H}_{2} \mathrm{O}, 1.81$ $\mathrm{gl}^{-1} ; \mathrm{ZnSO}_{4} .7 \mathrm{H}_{2} \mathrm{O}, 0.222 \mathrm{gl}^{-1} ; \mathrm{Na}_{2} \mathrm{MoO}_{4} \cdot 2 \mathrm{H}_{2} \mathrm{O}, 0.390 \mathrm{gl}^{-1} ; \mathrm{CuSO}_{4} .5 \mathrm{H}_{2} \mathrm{O}$, $0.079 \mathrm{gl}^{-1} ; \mathrm{Co}\left(\mathrm{NO}_{3}\right)_{2} .6 \mathrm{H}_{2} \mathrm{O}, 0-0494 \mathrm{gl}^{-1}$

\subsection{Statistical Analysis}

Descriptive statistics and Pearson's correlations between cyanobacterial density and different physico-chemical parameters of water were found using SPSS (version 17.0) statistical software.

\section{Results and Discussion}

\subsection{Temporal Variations of Physico-chemical Parameters of Water}

Analysis of monthly mean $\mathrm{pH}$, temperature, turbidity and dissolved oxygen in water of Nuwara wewa and Nachchaduwa wewa were carried out to compare the changes over time. According to the Department of Meteorology [16], Anuradhapura receives rainfall during the North East monsoon from October to February. However, a different pattern of rainfall was observed in 2012. The rain started in November and continued till May. Therefore, the water capacity of the study reservoirs measured in height increased during these months (Figures 2 and 3).

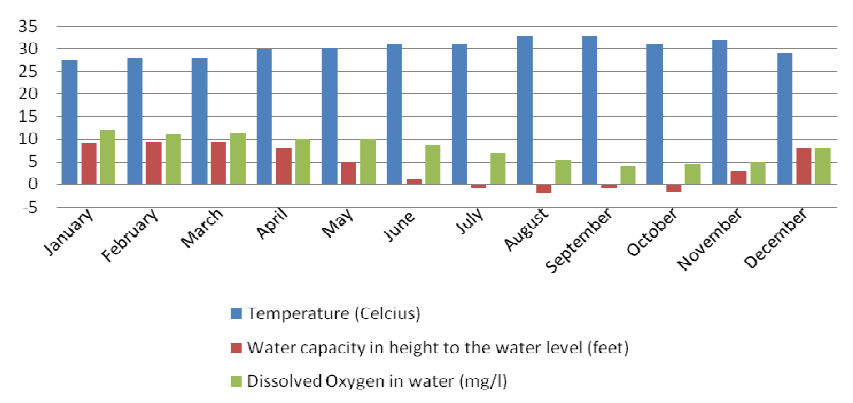

Figure 2. Temporal dynamics of physico-chemical parameters of water in Nuwara wewa

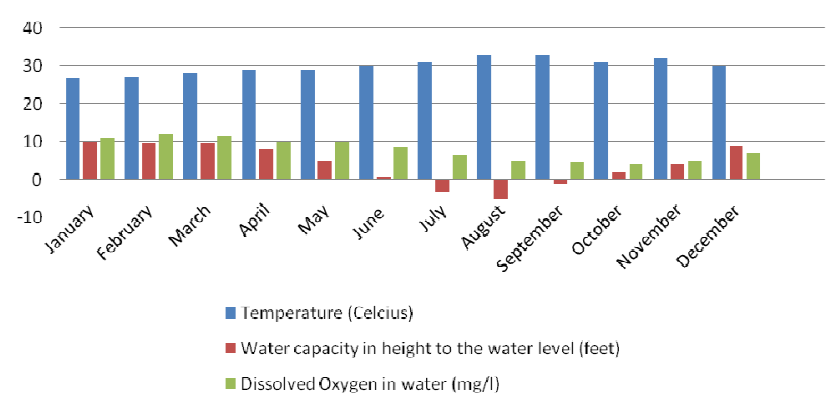

Figure 3. Temporal dynamics of physico-chemical parameters of water in Nachchaduwa wewa

During rainy season, the temperature was observed to be lower compared to dry spell (Figures 2 and 3). The highest temperature recorded was $30{ }^{\circ} \mathrm{C}$ in August and September in both Nuwara wewa and Nachchaduwa wewa (Tables 2 and 3). However, there was no much temperature fluctuation observed across the year. Dissolved oxygen levels in waters were low during the months which recorded lower water capacity (Figures 2 and 3). The highest $\mathrm{pH}$ values were recorded in the month of September in both Nuwara wewa and Nachchaduwa wewa and they were $8.78 \pm 0.09$ and $8.89 \pm 0.08$, respectively (Tables 2 and 3). The lowest $\mathrm{pH}$ was observed in the month of December in both Nuwara wewa and Nachchaduwa wewa with a value of $6.71 \pm 0.04$ and $6.44 \pm 0.16$, respectively (Tables 2 and 3). 
Table 2. Temporal dynamics of physico-chemical parameters of water and average density of cyanobacteria in Nuwara wewa

\begin{tabular}{lllllll}
\hline Month & $\begin{array}{l}\text { Avg. Density of } \\
\text { Cyanobacteria }\left(\mathbf{x 1 0}^{\mathbf{3}}\right)\end{array}$ & Mean pH & Temperature $\left.\mathbf{(}^{\mathbf{0}} \mathbf{C}\right)$ & Water level (feet) & Turbidity (NTU) & Dissolved $\mathbf{O}_{2}(\mathbf{m g} / \mathbf{l})$ \\
\hline January & 0.17 & $6.96 \pm 0.07$ & 27.5 & 9 & 3 & 12 \\
February & 0.33 & $7.21 \pm 0.09$ & 28 & 9.5 & 2 & 11 \\
March & 0.08 & $7.34 \pm 0.02$ & 28 & 9.5 & 2 & 11.5 \\
April & 0.25 & $7.78 \pm 0.09$ & 30 & 8 & 2.5 & 10 \\
May & 0.08 & $7.09 \pm 0.18$ & 30.5 & 5 & 5 & 10 \\
June & 0.17 & $8.36 \pm 0.09$ & 31 & 1 & 6 & 8.5 \\
July & 0.92 & $8.35 \pm 0.11$ & 31 & -1 & 7 & 7 \\
August & 2.08 & $8.35 \pm 0.12$ & 33 & -2 & 10 & 5.5 \\
September & 1.25 & $8.78 \pm 0.09$ & 33 & -1 & 8 & 4 \\
October & 0.42 & $7.10 \pm 0.23$ & 31 & -1.5 & 8.5 & 4.5 \\
November & 0.08 & $7.22 \pm 0.27$ & 32 & 3 & 5 & 5 \\
December & 0.08 & $6.71 \pm 0.04$ & 29 & 8 & & 8 \\
\hline
\end{tabular}

Table 3. Temporal dynamics of physico-chemical parameters of water and average density of cyanobacteria in Nachchaduwa wewa

\begin{tabular}{|c|c|c|c|c|c|c|}
\hline Month & $\begin{array}{l}\text { Avg. Density of } \\
\text { Cyanobacteria }\left(\mathbf{x 1 0}^{3}\right)\end{array}$ & Mean pH & Temperature $\left({ }^{0} \mathrm{C}\right)$ & Water level (feet) & Turbidity (NTU) & Dissolved $\mathrm{O}_{2}(\mathrm{mg} / \mathrm{l})$ \\
\hline January & 0.25 & $6.88 \pm 0.12$ & 27 & 10 & 5 & 11 \\
\hline February & 0.25 & $7.10 \pm 0.09$ & 27.4 & 9.5 & 3 & 12 \\
\hline March & 0.17 & $7.20 \pm 0.09$ & 28 & 9.5 & 2 & 11.5 \\
\hline April & 0.08 & $8.04 \pm 0.16$ & 29 & 8 & 7 & 10 \\
\hline May & 0.17 & $7.03 \pm 0.13$ & 29 & 5 & 8 & 10 \\
\hline June & 0.42 & $8.65 \pm 0.11$ & 30 & 1 & 10 & 8.5 \\
\hline July & 1.50 & $8.41 \pm 0.20$ & 31 & -3 & 12 & 6.5 \\
\hline August & 2.92 & $8.36 \pm 0.13$ & 33 & -5 & 18 & 5 \\
\hline September & 2.08 & $8.89 \pm 0.08$ & 33 & -1 & 12 & 4.5 \\
\hline October & 0.83 & $7.59 \pm 0.30$ & 31 & 2 & 10 & 4 \\
\hline November & 0.17 & $7.01 \pm 0.13$ & 32 & 4 & 9 & 5 \\
\hline December & 0.08 & $6.44 \pm 0.16$ & 30 & 9 & 6 & 7 \\
\hline
\end{tabular}

It was revealed that with higher water levels in the reservoirs, the dissolved oxygen in water was comparatively higher in both reservoirs (Tables 2 and 3). A very strong positive correlation was observed between the water level in Nuwara wewa and the dissolved oxygen in water of the reservoir (Table 4). These two parameters exhibited a strong positive correlation in Nachchaduwa wewa (Table 5) and it was significant at the $\alpha$ value of 0.01 . These results indicate that dissolved oxygen levels might have elevated due to mixing of water with atmospheric oxygen during rain fall as well as by runoff water from catchment areas.

Table 4. Pearson's correlation coefficients between different parameters of water in Nuwara wewa

\begin{tabular}{|c|c|c|c|c|c|c|}
\hline & Cyanobacterial Density & $\mathbf{p H}$ & Temperature & Water Level & Turbidity & Dissolved Oxygen \\
\hline Cyanobacterial Density & 1.00 & $0.69^{*}$ & $0.65^{*}$ & $-0.67^{*}$ & $0.67^{*}$ & -0.54 \\
\hline $\mathrm{pH}$ & $0.69^{*}$ & 1.00 & $0.67^{*}$ & $-0.66^{*}$ & 0.57 & -0.43 \\
\hline Temperature & $0.65^{*}$ & $0.67^{*}$ & 1.00 & $-0.88^{* *}$ & $0.92^{* *}$ & $-0.87^{* *}$ \\
\hline Water Level & $-0.66^{*}$ & $-0.66^{*}$ & $-0.88^{* *}$ & 1.00 & $-0.88^{* *}$ & $0.85^{* *}$ \\
\hline Turbidity & $0.67^{*}$ & 0.57 & $0.92^{* *}$ & $-0.88^{* *}$ & 1.00 & $-0.93^{* *}$ \\
\hline Dissolved Oxygen & -0.54 & -0.43 & $-0.87^{* *}$ & $0.85^{* *}$ & $-0.93^{* *}$ & 1.00 \\
\hline
\end{tabular}

* Correlation is significant at the 0.05 level (2-tailed).

** Correlation is significant at the 0.01 level (2-tailed).

Both reservoirs showed that the turbidity of water declined with the increase in water levels. The highest turbidity in Nuwara wewa being 12 NTU was recorded in September which received comparatively lower rain fall (Table 2). The Pearson's correlation analysis revealed that a very strong negative correlation $(r=-0.88)$ existed between the water level in Nuwara wewa and the turbidity (Table 4). Similar pattern was observed in Nachchaduwa wewa as well. A correlation coefficient of -0.77 was obtained between the water level and turbidity in Nachchaduwa wewa (Table 5). In rainy seasons especially in the North East monsoon, the turbidity was lower due to higher water capacity and flushing of solids during water discharge. According to the World Health Organization, suitable standard turbidity value for consumption should be less than 1 NTU. Therefore, the water from both of the reservoirs is not suitable for direct consumption without treatment. 
Table 5. Pearson's correlation coefficients between different parameters of water in Nachchaduwa wewa

\begin{tabular}{lllllll}
\hline & Cyanobacterial Density & $\mathbf{p H}$ & Temperature & Water Level & Turbidity & Dissolved Oxygen \\
\hline Cyanobacterial Density & 1.00 & $0.68^{*}$ & $0.74^{* *}$ & $-0.85^{* *}$ & $0.85^{* *}$ & $-0.61^{*}$ \\
$\mathrm{pH}$ & $0.68^{*}$ & 1.00 & 0.56 & $-0.77^{* *}$ & $0.67^{*}$ & -0.40 \\
Temperature & $0.74^{* *}$ & 0.56 & 1.00 & $-0.84^{* *}$ & $0.86^{* *}$ & $-0.93^{* *}$ \\
Water Level & $-0.85^{* *}$ & $-0.77^{* *}$ & $-0.84^{* *}$ & 1.00 & $-0.94^{* *}$ & $0.74^{* *}$ \\
Turbidity & $0.85^{* *}$ & $0.67^{*}$ & $0.86^{* *}$ & $-0.94^{* *}$ & 1.00 & $-0.77^{* *}$ \\
Dissolved Oxygen & $-0.61^{* *}$ & -0.37 & $-0.93^{* *}$ & $0.74^{* *}$ & $-0.77^{* *}$ & 1.00 \\
\hline
\end{tabular}

*. Correlation is significant at the 0.05 level (2-tailed).

${ }^{* *}$. Correlation is significant at the 0.01 level (2-tailed)

Pearson's correlation analysis between turbidity and dissolved oxygen in both reservoirs disclosed a negative correlation with the coefficients of -0.93 and -0.77 in Nuwara wewa and Nachchaduwa wewa, respectively (Tables 4 and 5). The elevated turbidity might be due to mixing and concentrating of organic materials which in turn might have undergone decomposition reducing the total dissolved oxygen in waters.

A very strong negative correlation between the temperature and the dissolved oxygen was observed (Tables 4 and 5). This may be due to two reasons: (i) dissolved oxygen in water gets evolved from water with elevated temperature and (ii) at temperature ranging from $30-33{ }^{\circ} \mathrm{C}$, cyanobacteria proliferate making the reservoir eutrophic, prevent penetration of sunlight into the reservoir and decrease the physical contact of atmosphere with water, all contributing to the decline in dissolved oxygen [12].

\subsection{Space-Time Dynamics of Cyanobacteria}

Bottom and the water column of each reservoir had been always changing with the changes of the environment and weather parameters. The correlation analysis revealed that a strong positive correlation existed between the $\mathrm{pH}$ of the water in the study reservoirs and the cyanobacterial density (Tables 4 and 5). The highest cyanobacterial density was observed at a $\mathrm{pH}$ range of $8.00-8.50$ (Table 2 and 3). This result is in line with the findings by Soumati et al. [12] in Cheffia dam in the North-East of Algeria.

Temperature also had a strong positive correlation with the cyanobacterial density within a particular range (Tables 4 and 5). Soumati et al. [12] stated that the presence of toxic cyanobacteria correlates with a moderate temperature $(15-30$ $\left.{ }^{0} \mathrm{C}\right)$ [17]. However, the cyanobacteria density and the dissolved oxygen in water exhibited a moderate negative correlation (Tables 4 and 5). This may be owing to the proliferation of cyanobacteria. Cyanobacterial bloom makes a mat of algae on the surface of waters preventing the physical contact with atmosphere and decreasing the penetration of sunlight into water [18]. Poor penetration of sunlight into water lowers the photosynthesis by submerged autotrophic flora in the water. This leads to net decline in dissolved oxygen in water. Further, respiration during nighttime can deplete dissolved oxygen concentration to a critical level. Oxidative decomposition of organic compounds derived from dead planktons and wastes of fish and aquatic animal would have also decreased the level of dissolved oxygen. These processes could have contributed to the depletion of the available dissolved oxygen in the water. Therefore, these parameters ( $\mathrm{pH}$, temperature and dissolved oxygen) can be used a good indicators to evaluate the status of a water body in terms of cyanobacterial density and distribution. In both reservoirs, the cyanobacterial density declined with the increase in water level (Figure 4). This may be due to low density of the cyanobacterial population because of higher volume of water as well as the unfavorable condition of water in the reservoirs for cyanobacterial proliferation. Chorus and Bartram [8] stated that when temperature, light and nutrient status are conducive, surface water may host augmented growth of cyanobacteria. The period from July to September was a dry spell and the temperature was also slightly high favoring the proliferation of cyanobacteria. Toxic cyanobacteria produce cyanobacterial toxins like microcystin during high growth or high metabolism [3]. Therefore, measures should be taken to reduce the cyanobacterial population or completely eliminate them during this period.

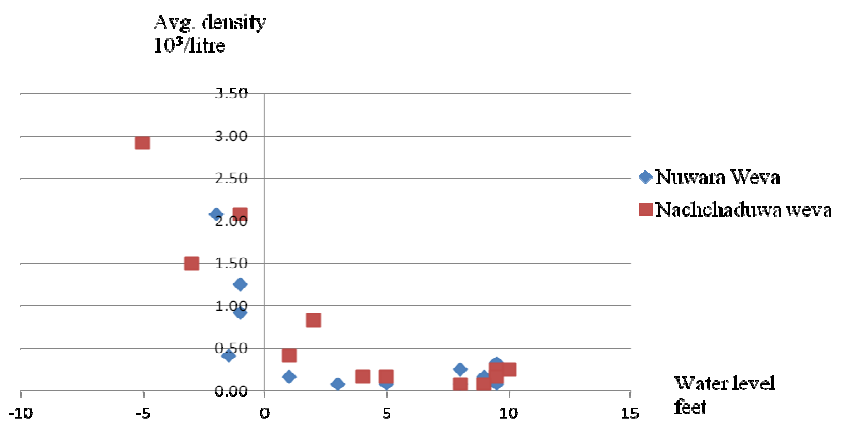

Figure 4. Variation of average monthly density of cyanobacteria with water level

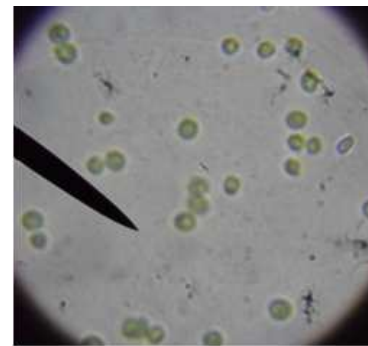

(1)

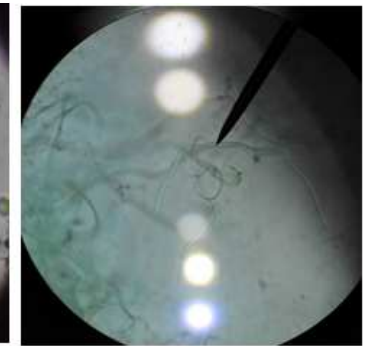

(2)
(Magnification x 1000)

Figure 5. Morphology of Chroococcidiopsis (1) and Cylindrospermopsis (2) through light microscope 
In most of the eutrophic and hypertrophic lakes, Microcystis, Planktothrix and Anabaena are the major microcystin producing cyanobacterial genera [3, 8, 19, 20, 21]. According to the standard identification keys, many of the isolates recovered in this study were identified as Chroococcidiopsis and Cylindrospermopsis isolates through microscopic observations (Figure 5). Magana-Arachchi and Wanigatunge [22] also disclosed the prevalence of the genus Chroococcidiopsis in dry zone waters in Sri Lanka.

\section{Conclusion}

Strong positive correlations exist between physico-chemical parameters $(\mathrm{pH}$, temperature and dissolved oxygen) of water in both Nuwara wewa and Nachchaduwa wewa and the cyanobacterial density. These parameters can be used as good indicators to evaluate the status these reservoirs in terms of cyanobacterial density and distribution.

\section{Acknowledgements}

We would like to express our sincere gratitude to the National Research Council, Sri Lanka for the financial support through NRC Grants 2011 (NRC Grant No. 11-07).

\section{References}

[1] M.C.M. Zakeel, (2001), Chronic Renal Failure and Its Etiology (Feature article). YSF Newsletter, vol. 1, Young Scientists Forum, National Science and Technology Commission, Sri Lanka.

[2] D.M. Dissanayake, J.M. Jayasekera, P. Ratnayake, W. Wickramasinghe and Y.A. Radella, (2011), The short term effect of cyanobacterial toxin extracts on mice kidney. Proceedings of the Peradeniya University Research Sessions: University of Peradeniya (LK), p. 13.

[3] W. Ye, X. Liu, J. Tan, D. Li and H. Yang, (2009), Diversity and dynamics of microcystin-producing cyanobacteria in China's third largest lake, Lake Taihu. Harmful Algae, vol. 8, pp. 637-644.

[4] W.W. Carmichael, S.M.F.O. Azevedo, J.S. An, J.R. Molica, E.M. Jochimsen, S. Lau, K.L. Rinehart, G.R. Shaw and G.K. Eaglesham, (2001), Human Fatalities from Cyanobacteria: Chemical and Biological Evidence for Cyanotoxins. Envirn. Health Persp., vol. 109, pp. 663-668.

[5] I.R. Falconer, J.V. Smith, A.R.B. Jackson, A. Jones and M.T.C. Runnegar, (1988), Oral toxicity of abloom of the cyanobacterium Microcystis aeruginosa administered to mice over periods up to 1 year. J. Toxicol. Environ. Health, vol. 24, pp. 291-305.

[6] P. Cohen, (1989), The structure and regulation of protein phosphatases. Annu. Rev. Biochem, vol. 58, pp. 453-508.

[7] R.B. Fitzgeorge, S.A. Clark and C.W. Keevil, (1994), Routes of intoxication. In: International Symposium on Detection Methods for Cyanobacterial (Blue-Green Algal) Toxins. pp. 69-74. G.A. Codd, T.M. Jeffries, C.W. Keevil and E. Potter (eds.). Royal Society of Chemistry, Cambridge, UK.
[8] I. Chorus and J. Bartram, (1999), Toxic Cyanobacteria in Water: A Guide to their Public Health Consequences, Monitoring and Management. Spoon, London, pp. 41- 111.

[9] K. Sivonen and G. Jones, (1999), Toxic cyanobacteria in water: a guide to public health significance, monitoring and management. In: Chorus I., Bertram J. Cyanobacterial toxins, E \& FN Spon, London, United Kingdom, pp. 41-111.

[10] T.W. Lambert, C.F.B. Holmes and S.E. Hrudey, (1996), Absorption of microcystins - LR by activated carbon and removal in full scalewater treatment. Wat. Res., vol. 30, pp. $1411-1422$.

[11] C.E. Boyd, (2005), Production Sustainable Aquaculture Practices; Copper Treatments Control Phytoplankton. Global Aquaculture Advocate, p. 69.

[12] B. Soumati, H. Nasri, A. Meddour, S. Kadri and N. Loucif, (2005), Space-time dynamics and parameters of growth of toxic cyanobacteria in freshwaters in cheffia dam (North-East of Algeria). Ninth International Water Technology Conference, Egypt, pp. 755-764.

[13] R.Y. Stanier, R. Kunisawa, M. Mandel and G. Cohen-Bazire, (1971), Purification and properties of unicellular blue-green algae (order Chroccoccales). Bacteriol. Rev., vol. 35, pp. 171-205.

[14] L. Lawton, B. Marsalek, J. Padisak, I. Chorus and J. Bartram, (1999), Determination of Cyanobacteria in the Laboratory (Chapter 12). Toxic Cyanobacteria in Water: A guide to their public health consequences, monitoring and management. WHO, ISBN 0-419-23930-8.

[15] R. Rippka, J. Deruelles, J.B. Waterbury, M. Herdman and R.Y. Stanier, (1979), Generic Assignments, Strain Histories and Properties of Pure Cultures of Cyanobacteria, J. Gen. Microbiol., vol. 111, pp. 1-61.

[16] Department of Meteorology, Sri Lanka. Available at: www.meteo.gov.lk. (Accessed: 16 July 2014).

[17] Prentice and M. James, (2008), Temporal and spatial variations of cyanobacteria in Karori Reservoir, Wellington. MSc Thesis, The University of Wellington. Available at: http://waikato.researchgateway.ac.nz/ (Accessed: 16 July 2014).

[18] K. Kunlasak, C. Chitmanat, N. Whangchai, J. Promya and L. Label, (2013), Relationship of dissolved oxygen with chlorophyll-a and phytoplankton composition in Tilapia ponds, Int. J. Geosci., vol. 4, pp. 46-53.

[19] W.W. Carmichael and I.R. Falconer, (1993). Diseases related to freshwater blue green algal toxins, and control measures. In: Algal Toxins in Seafood and Drinking Water, pp. 187-209. I.R. Falconer (ed.)., Academic Press, New York.

[20] W.W. Carmichael, (1994), The toxins of cyanobacteria. Sci. Am., vol. 270, pp. 78-86.

[21] L.E. Fleming and W. Stephan, (2001). Blue green algae, their toxins and public health issues. The Florida Harmful Algal Bloom Taskforce, Florida St. Petersburg, Florida.

[22] D.N. Magana-Arachchi and R.P. Wanigatunge, (2013), First report of genus Chroococcidiopsis (cyanobacteria) from Sri Lanka: a potential threat to human health. J. Natn. Sci. Foundation Sri Lanka, vol. 41, pp. 65-68. 